\title{
Front Matter: Volume 10958
}

, "Front Matter: Volume 10958," Proc. SPIE 10958, Novel Patterning Technologies for Semiconductors, MEMS/NEMS, and MOEMS 2019, 1095801 (26 June 2019); doi: 10.1117/12.2534600 


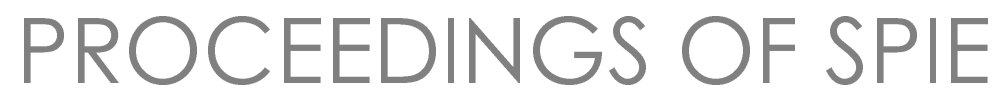

\section{Novel Patterning Technologies for Semiconductors, MEMS/NEMS, and MOEMS 2019}

Martha I. Sanchez

Eric M. Panning

Editors

25-28 February 2019

San Jose, California, United States

Sponsored and Published by

SPIE

Volume 10958 
The papers in this volume were part of the technical conference cited on the cover and title page. Papers were selected and subject to review by the editors and conference program committee. Some conference presentations may not be available for publication. Additional papers and presentation recordings may be available online in the SPIE Digital Library at SPIEDigitalLibrary.org.

The papers reflect the work and thoughts of the authors and are published herein as submitted. The publisher is not responsible for the validity of the information or for any outcomes resulting from reliance thereon.

Please use the following format to cite material from these proceedings:

Author(s), "Title of Paper," in Novel Patterning Technologies for Semiconductors, MEMS/NEMS, and MOEMS 2019, edited by Martha I. Sanchez, Eric M. Panning, Proceedings of SPIE Vol. 10958 (SPIE, Bellingham, WA, 2019) Seven-digit Article CID Number.

ISSN: 0277-786X

ISSN: 1996-756X (electronic)

ISBN: 9781510625631

ISBN: 9781510625648 (electronic)

Published by

SPIE

P.O. Box 10, Bellingham, Washington 98227-0010 USA

Telephone +13606763290 (Pacific Time) · Fax +1 3606471445

SPIE.org

Copyright @ 2019, Society of Photo-Optical Instrumentation Engineers.

Copying of material in this book for internal or personal use, or for the internal or personal use of specific clients, beyond the fair use provisions granted by the U.S. Copyright Law is authorized by SPIE subject to payment of copying fees. The Transactional Reporting Service base fee for this volume is $\$ 18.00$ per article (or portion thereof), which should be paid directly to the Copyright Clearance Center (CCC), 222 Rosewood Drive, Danvers, MA 01923. Payment may also be made electronically through CCC Online at copyright.com. Other copying for republication, resale, advertising or promotion, or any form of systematic or multiple reproduction of any material in this book is prohibited except with permission in writing from the publisher. The CCC fee code is 0277$786 \times / 19 / \$ 18.00$.

Printed in the United States of America by Curran Associates, Inc., under license from SPIE.

Publication of record for individual papers is online in the SPIE Digital Library.

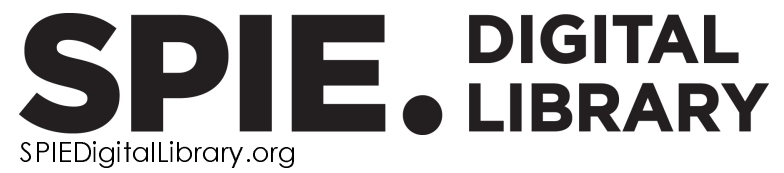

Paper Numbering: Proceedings of SPIE follow an e-First publication model. A unique citation identifier (CID) number is assigned to each article at the time of publication. Utilization of CIDs allows articles to be fully citable as soon as they are published online, and connects the same identifier to all online and print versions of the publication. SPIE uses a seven-digit CID article numbering system structured as follows:

- The first five digits correspond to the SPIE volume number.

- The last two digits indicate publication order within the volume using a Base 36 numbering system employing both numerals and letters. These two-number sets start with $00,01,02,03,04$, 05, 06, 07, 08, 09, OA, OB ... 0Z, followed by 10-1Z, 20-2Z, etc. The CID Number appears on each page of the manuscript. 


\title{
Contents
}

\author{
vii Authors \\ xi Conference Committee \\ xiii Introduction
}

KEYNOTE SESSION

1095803 Will stochastics be the ultimate limiter for nanopatterning? (Keynote Paper) [10958-2]

MEMS/NEMS AND MOEMS I

1095806 3D printing functional nano-photonic devices by multi-photon lithography (Invited Paper) [10958-5]

MEMS/NEMS AND MOEMS II

109509 Grayscale lithography process study for sub 5 $\mu \mathrm{m}$ microlens patterns [10958-8]

NANOIMPRINT LITHOGRAPHY I: TECHNOLOGY

$10958 \mathrm{OB} \quad$ Nanoimprint system alignment and overlay improvement for high volume semiconductor manufacturing [10958-10]

10958 OC Topography and flatness induced overlay distortion correction using resist drop pattern compensation in nanoimprint systems [10958-11]

10958 OD Substrate conformal imprint lithography: functional resists, overlay performance, and volume production results [10958-12\}

NANOIMPRINT LITHOGRAPHY II: MANUFACTURING

10958 OG The advantages of nanoimprint lithography for semiconductor device manufacturing [10958-15]

$10958 \mathrm{OH} \quad$ Half-pitch 14nm direct patterning with nanoimprint lithography [10958-16] 
MULTI-BEAM LITHOGRAPHY: INVITED SESSION

10958 0J Multi-beam mask writer MBM-1000 (Invited Paper) [10958-18]

DIRECTED SELF-ASSEMBLY I: JOINT SESSION WITH CONFERENCES 10960 AND 10958

$10958 \mathrm{OL} \quad$ Electrical validation of the integration of 193i and DSA for sub-20nm metal cut patterning [10958-20]

10958 OM Spacer patterning lithography as a new process to induce block copolymer alignment by chemo-epitaxy [10958-21]

10958 ON LCDU improvement of EUV-patterned vias with DSA [10958-22]

NOVEL PATTERNING AND APPLICATIONS I

1095800 Insights on reflection: new ideas gained from comparing femtosecond laser development, microscopy, and patterning (Invited Paper) [10958-23]

$10958 \mathrm{OP} \quad$ Nanofabrication in extended areas on the basis of nanopositioning and nanomeasuring machines (Invited Paper) [10958-24]

$109580 Q \quad$ Next generation of heated atomic force microscope cantilever for nanolithography: modelling, simulation, and nanofabrication [10958-25]

NOVEL PATTERNING AND APPLICATIONS II

10958 OY Patterning challenges for beyond 3nm logic devices: example of an interconnected magnetic tunnel junction [10958-33]

NOVEL MATERIALS/NOVEL DIRECTED SELF-ASSEMBLY

$1095811 \quad$ Novel approach to sub-5-nm patterning platforms: the self-assembly of metal conjugated bioinspired molecules [10958-36]

$1095812 \quad$ An alternative line-space shrink EUVL plus complementary DSA lithography [10958-37]

iv 
POSTER SESSION

1095814 Oxygen effects in thin films for high-resolution, 3-color lithography [10958-39]

1095816 Evaluation of adhesion layers performances for soft UV nanoimprint lithography [10958-41]

109518 Gas permeable mold for defect reduction in nanoimprint lithography [10958-43]

$1095819 \quad$ Integrated soft UV-nanoimprint lithography in a nanopositioning and nanomeasuring machine for accurate positioning of stamp to substrate [10958-44]

10958 1D Spatial coherence properties of an LED-based illumination system for mask-aligner lithography [10958-48]

10958 1E Beyond contrast curve approach: a grayscale model applied to sub-5 $\mu$ m patterns [10958-49]

10958 1F Tilted ion implantation of spin-coated SiARC films for sub-lithographic and two-dimensional patterning [10958-50]

10958 1K Defects in nano-imprint lithography line patterns: computational modelling and measurement accuracy [10958-56] 
Proc. of SPIE Vol. 10958 1095801-6

Downloaded From: https://www.spiedigitallibrary.org/conference-proceedings-of-spie on 26 Apr 2023 Terms of Use: https://www.spiedigitallibrary.org/terms-of-use 


\section{Authors}

Numbers in the index correspond to the last two digits of the seven-digit citation identifier (CID) article numbering system used in Proceedings of SPIE. The first five digits reflect the volume number. Base 36 numbering is employed for the last two digits and indicates the order of articles within the volume. Numbers start with 00, 01, 02, 03, 04, 05, 06, 07, 08, 09, OA, OB...0Z, followed by 10-12, 20-2Z, etc.

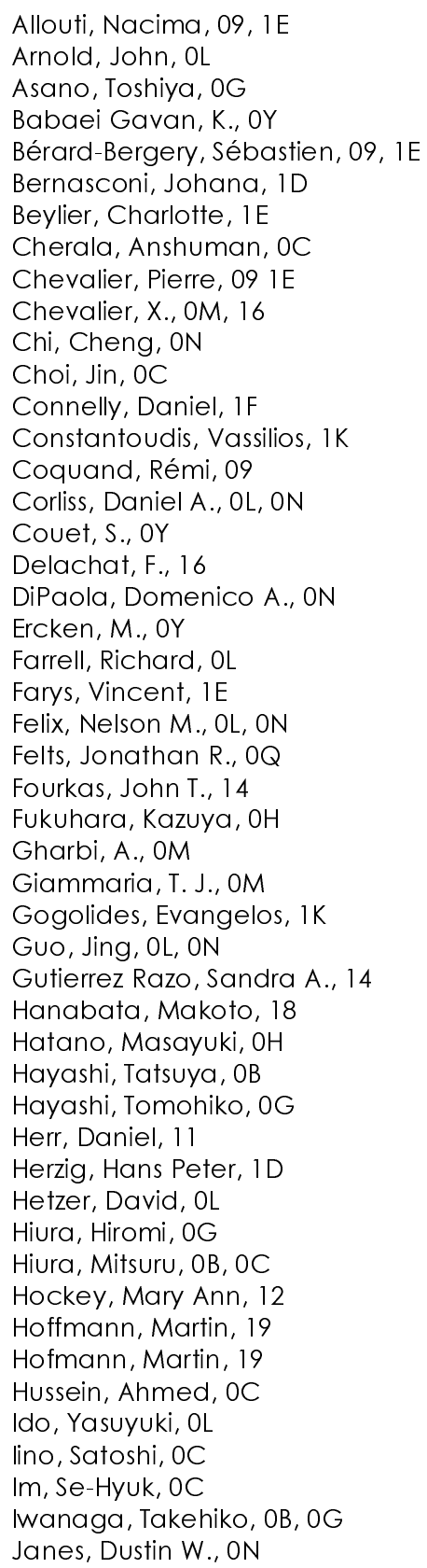

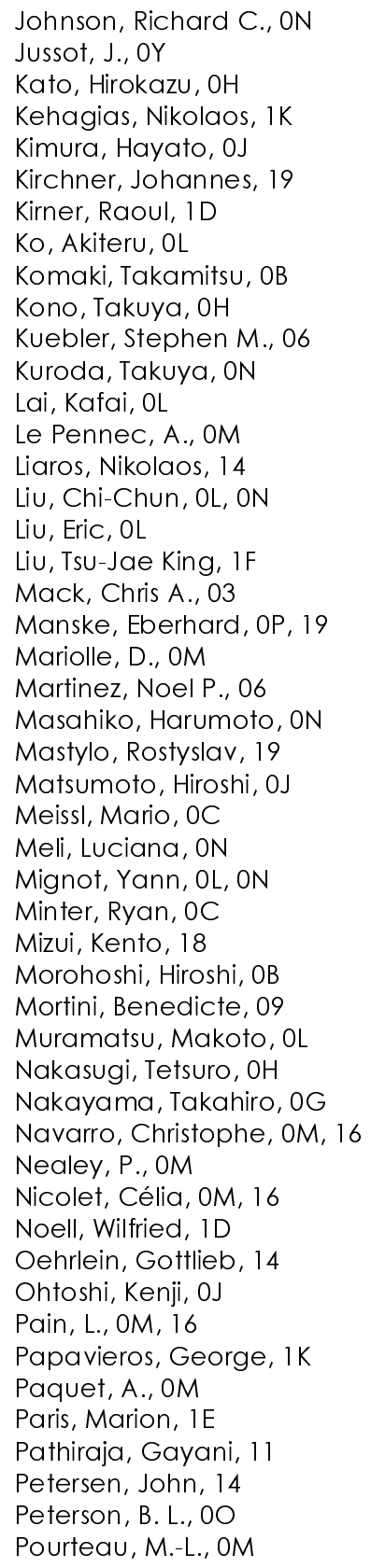


Pranda, Adam, 14

Quéméré, Patrick, 09, $1 \mathrm{E}$

Rademaker, G., OM

Radu, I. P., OY

Rangelow, Ivo W., 19

Rassoul, N., OY

Rathnayake, Hemali, 11

Raymenants, E., OY

Rembert, Thomas R., $1 \mathrm{~F}$

Resnick, Douglas J., OG

Ridderbeek, Korneel, OD

Rousset, Valérie, 09

Rubin, Leonard, $1 \mathrm{~F}$

Rumpf, Raymond C., 06

Sakai, Keita, OG

Sakavuyi, K., OM

Scharf, Toralf, 1D

Sharma, Rashi, 06

Sharma, Shalini, 1F

Simpson, Logan, OC

Sinzinger, Stefan, 19

Soleymaniha, Mohammadreza, $\mathrm{OQ}$

Sotomoyor Torres, Clivia M., $1 \mathrm{~K}$

Souriau, L., OY

Supreeti, Shraddha, 19

Swerts, J., OY

Takabayashi, Yukio, OB, OG

Takei, Satoshi, 18

Tamura, Takao, OJ

Tanaka, Yuji, ON

Teyssedre, H., 16

Thiam, N. A., OY

Thompson, Ecron, OC

Tiron, R., OM

Tokue, Hiroshi, $\mathrm{OH}$

Tomaso, Florian, 09

Touma, Jimmy, 06

Trivkovic, D., OY

Vaillant, Jérôme, $1 \mathrm{E}$

Verschuuren, Marc A., OD

Voelkel, Reinhard, 1D

Voorkamp, Rob, OD

Wan, D., OY

Whitworth, Guy, 1K

Wilson, C. J., OY

Xia, Chun, 06

Yamamoto, Kiyohito, $0 G$

Yang, Geng, 06 


\title{
Conference Committee
}

\author{
Symposium Chair \\ Will Conley, Cymer, an ASML Company (United States) \\ Symposium Co-chair \\ Kafai Lai, IBM Thomas J. Watson Research Center (United States) \\ Conference Chair
}

Martha I. Sanchez, IBM Research - Almaden (United States)

Conference Co-chair

Eric M. Panning, Intel Corporation (United States)

Conference Program Committee

Alan D. Brodie, KLA Corporation (United States)

Juan J. de Pablo, The University of Chicago (United States)

Richard A. Farrell, TEL Technology Center, America, LLC (United States)

Naoya Hayashi, Dai Nippon Printing Company, Ltd. (Japan)

Tatsuhiko Higashiki, Toshiba Corporation (Japan)

Erik R. Hosler, GLOBALFOUNDRIES Inc. (United States)

J. Alexander Liddle, National Institute of Standards and Technology (United States)

Chi-Chun Liu, IBM Corporation (United States)

Hans Loeschner, IMS Nanofabrication $\mathrm{GmbH}$ (Austria)

John G. Maltabes, Applied Materials GmbH \& Company KG (United States)

Laurent Pain, CEA-LETI (France)

Ivo W. Rangelow, Technische Universität Ilmenau (Germany)

Douglas J. Resnick, Canon Nanotechnologies, Inc. (United States)

Ricardo Ruiz, HGST (United States)

Chandrasekhar Sarma, Intel Corporation (United States)

Helmut Schift, Paul Scherrer Institut (Switzerland)

Ines A. Stolberg, Vistec Electron Beam GmbH (Germany)

Hsinyu Tsai, IBM Research - Almaden (United States)

Kevin T. Turner, University of Pennsylvania (United States)

Marco J. Wieland, MAPPER Lithography (Netherlands)

Wei Wu, The University of Southern California (United States) 
Session Chairs

1 Keynote Session

Martha I. Sanchez, IBM Research - Almaden (United States)

Eric M. Panning, Intel Corporation (United States)

2 MEMS/NEMS and MOEMS I

J. Alexander Liddle, National Institute of Standards and Technology (United States)

John G. Maltabes, Applied Materials GmbH \& Company KG (United States)

3 MEMS/NEMS and MOEMS II

Hsinyu Tsai, IBM Research - Almaden (United States)

Alan D. Brodie, KLA Corporation (United States)

4 Nanoimprint Lithography I: Technology

Chi-Chun Liu, IBM Corporation (United States)

Chandrasekhar Sarma, Intel Corporation (United States)

$5 \quad$ Nanoimprint Lithography II: Manufacturing

Douglas J. Resnick, Canon Nanotechnologies, Inc. (United States)

Tatsuhiko Higashiki, Toshiba Corporation (Japan)

6 Multi-beam Lithography: Invited Session

Ines A. Stolberg, Vistec Electron Beam GmbH (Germany)

Hans Loeschner, IMS Nanofabrication GmbH (Austria)

7 Directed Self-assembly I: Joint Session with Conferences 10960 and 10958

Raluca Tiron, CEA-LETI (France)

Ricardo Ruiz, HGST (United States)

8 Novel Patterning and Applications I

Naoya Hayashi, Dai Nippon Printing Co., Ltd. (Japan)

Erik R. Hosler, GLOBALFOUNDRIES Inc. (United States)

9 3-D Printing and Structures: Invited Session

Ivo W. Rangelow, Technische Universität IImenau (Germany)

Richard A. Farrell, TEL Technology Center, America, LLC (United States)

10 Neuromorphic Computing: Invited Session

Laurent Pain, CEA-LETI (France)

J. Alexander Liddle, National Institute of Standards and Technology (United States) 
11 Novel Patterning and Applications II

Martha I. Sanchez, IBM Research - Almaden (United States)

Eric M. Panning, Intel Corporation (United States)

12 Novel Materials/Novel Directed Self-assembly

Martha I. Sanchez, IBM Research - Almaden (United States)

Eric M. Panning, Intel Corporation (United States)

Proc. of SPIE Vol. 10958 1095801-11

Downloaded From: https://www.spiedigitallibrary.org/conference-proceedings-of-spie on 26 Apr 2023 Terms of Use: https://www.spiedigitallibrary.org/terms-of-use 
Proc. of SPIE Vol. 10958 1095801-12 Downloaded From: https://www.spiedigitallibrary.org/conference-proceedings-of-spie on 26 Apr 2023
Terms of Use: https://www.spiedigitallibrary.org/terms-of-use 


\section{Introduction}

The Novel Patterning Technologies for Semiconductors, MEMS/NEMS and MOEMS 2019 Conference is a forum for new solutions to meet current and future patterning challenges. Extending scaling or complementing existing approaches is in scope and this year we expanded beyond traditional wafer pattering to address emerging patterning challenges in MEMS/NEMS and MOEMS with 2 sessions of invited speakers.

The MEMS/NEMS and MOEMS space is at the interface between microelectronics and the physical world, acting often as sensors or actuators in the automobile industry, medical devices and military, for example. They face challenges defined by patterning high aspect ratio features and extreme topography with similar critical dimensions to microelectronics in cases. Successful patterning requires meeting complex material, mechanical and topology constraints.

This year the Novel Patterning Conference had 56 invited and contributed papers. The conference began on Monday afternoon with two Keynote presentations. A third Keynote talk on Tuesday morning kicked off the new MEMS/NEMS and MOEMS topic. There were 7 major topics, 12 oral sessions, and a poster session held on Wednesday evening.

The conference kicked off with two Keynote presentations, Donald Tennant, from Cornell University (United States), spoke about "The evolution of the Cornell NanoScale Facility and synergies with the semiconductor Industry". He discussed the history leading up to the Cornell NanoScale Facility and the range of projects researched at the CNF serving industry and academia. Chris Mack's (Fractilia, United States) talk "Will stochastics be the ultimate limiter for nanopatterning?" further elaborated on Tennant's Law. Combined, the talks reviewed the tremendous progress made in patterning as well as the challenges ahead in achieving further resolution improvement without running into stochastics limitations.

The third Keynote presentation was from Daniel Lopez from Argonne National Laboratory (Unted States). His talk "Integration of metasurfaces onto micro electro mechanical systems for active control of visible and IR light" began our 2 Invited sessions on MEMS/NEMS and MOEMS. Metasurfaces in optics is a way of achieving high quality imaging with minimal stack height by material choice and placement.

There were two more new topics, both invited sessions on Neuromorphic Computing and 3D Printing. Additionally, there was an invited session on multi- 
beam lithography, two sessions on nanoimprint, a DSA joint session with the Advances in Patterning Materials and Processes Conference covering new materials, integration, and characterization, and three sessions on novel patterning and/or materials.

Finally, we would like to thank those program committee members who took the time and effort to review abstracts and contributed to making a technically strong program. We look forward to expanding our novel patterning topics, and your continued contributions to new patterning technologies. One new topic for 2020 will be flat panel displays and advanced packaging tools/techniques.

Martha I. Sanchez Eric M. Panning 